\title{
References:
}

1.Pro skhvalennya Kontseptsiyi realizatsiyi derzhavnoyi polityky shchodo sotsial'noho zakhystu naselennya ta zakhystu prav ditey. Rozporyadzhennya Kabinetu Ministriv Ukrayiny vid 26 serpnya 2020 r. № 1057-p. URL: https://zakon.rada.gov.ua/laws/show/1057-2020-\%D1\%80\#Text

2.Yakovlyeva H. Derzhavnyy nahlyad i kontrol' u sferi sotsial'noho zabezpechennya naselennya Ukrayiny. Pidpryyemnytstvo, hospodarstvo i pravo. 2017. № 4. S.90-93. URL: http://nbuv.gov.ua/UJRN/Pgip_2017 4 20

3.Pro zatverdzhennya Polozhennya pro Ministerstvo sotsial'noyi polityky Ukrayiny: postanova Kabinetu Ministriv Ukrayiny vid 17.06.2015 r. \# 423. URL: https://zakon.rada.gov.ua/laws/show/423-2015-\%D0\%BF\#Text (data zvernennya 20.09.2020). 4.Deyaki pytannya Natsional'noyi sotsial'noyi servisnoyi sluzhby Ukrayiny: postanova Kab. Ministriv Ukrayiny vid 26.08.2020 r. № 783. Uryadovyy kur"yer. 2020. 5 veres. S. 10-11. URL: https://zakon.rada.gov.ua/laws/show/783-2020$\%$ D0\%BF\#n44

5.Proyekty, shcho pidtrymuyut'sya MBRR / Miniterstvo sotsial'noyi polityky. Vebsayt: URL: https://www.msp.gov.ua/timeline/Proekti-shcho-pidtrimuyutsya-

MBRR.html?fbclid=IwAR2RcF5EemR9T7oBRaXgYY1sQmbK-6dp-EF-ntidcRVWECnFKAmHKrAFR_A

(data zvernennya 20.03.2021 r.)

6.Minsotspolityky posylyt' uvahu do yakosti sotsial'nykh posluh dlya naymensh zakhyshchenykh hromadyan/ Miniterstvo sotsial'noyi polityky. Vebsayt:. URL: https://www.msp.gov.ua/news/18931.html data zvernennya 12.03.2021 r.)

7.Deyaki pytannya zdiysnennya kontrolyu za doderzhannyam vymoh Zakonu Ukrayiny «Pro sotsial'ni posluhy»: postanova Kab. Ministriv Ukrayiny vid 01.06.2020 r. \# 427. Uryadovyy kur"yer. 2020. 3 cherv. S. 5.; Pro zatverdzhennya Poryadku provedennya monitorynhu nadannya ta otsinky yakosti sotsial'nykh posluh: postanova Kab. Ministriv Ukrayiny vid 01.06.2020 r. \# 448. Uryadovyy kur"yer. 2020. 6 cherv. S. 5-6.

8.Pro veryfikatsiyu ta monitorynh derzhavnykh vyplat. Zakon Ukrayiny vid 3 hrudnya 2019 roku \# 324-IX. Vidomosti Verkhovnoyi Rady Ukrayiny, 2020, \# 11, st.63. URL: https://zakon.rada.gov.ua/laws/show/324-20\#Text;;

9.Pro zatverdzhennya Poryadku zdiysnennya veryfikatsiyi ta monitorynhu derzhavnykh vyplat. Postanova Kabinetu ministriv vid 18 lyutoho 2016 r. \# 13. Iz zminamy, vnesenymy z-hidno z Postanovamy KM \# 443 vid 22.05 .2019 \# 205 vid 03.03.2020. URL: https://zakon.rada.gov.ua/laws/show/136-2016-\%D0\%BF\#n10

10. Pro Reyestr nadavachiv ta otrymuvachiv sotsial'nykh posluh: postanova Kabinetu Ministriv Ukrayiny vid 27 sichnya 2021 r. \# 99. URL: https://zakon.rada.gov.ua/laws/show/99-2021-\%D0\%BF\#Text

11. Pro zaprovadzhennya eksperymental'noho proektu $\mathrm{z}$ realizatsiyi funktsionaliv pershoyi cherhy Yedynoyi informatsiynoyi systemy sotsial'noyi sfery: postanova Kabinetu Ministriv Ukrayiny vid 11.11.2020 r. \# 1278 URL: https://zakon.rada.gov.ua/laws/show/1278-2020-\%D0\%BF\#n30

12. Proyekt Pro zatverdzhennya Polozhennya pro Yedynu informatsiynu systemu sotsial'noyi sfery URL: https://www.msp.gov.ua/projects/653/

13. Pro utvorennya robochoyi hrupy z pytan' udoskonalennya zakonodavstva shchodo rozvytku i rehulyuvannya rynku sotsial'nykh posluh. Postanova Kabinetu ministriv vid 17 lyutoho 2021 r. № 125 . URL: https://zakon.rada.gov.ua/laws/show/125-2021-\%D0\%BF\#Text

Дата подання публікації 01.04.2021 p.

УДК 364:005.591.6(477)

Савченко В.Ф., д.е.н., професор Уманський державний педагогічний університет імені Павла Тичини V.F. Savchenko, Doctor of Economic Sciences,Professor PavloTychynaUman State Pedagogical University https://orcid.org/0000-0001-7637-2124

Маклюк О.В., викладач

Чернігівський інститут імені Героїв Крут Приватного акціонерного товариства «Вищий навчальний заклад «Міжрегіональна Академія управління персоналом»

Oleh Makliuk, Lecturer

Chernihiv Institute named after Heroes of Kruty PJSC Private Joint-Stock Company «Higher education institution «Interregional Academy of Personnel Management» https://orcid.org/0000-0002-7429-692X

\section{ІННОВАЦІЙНІ ПІДХОДИ ДО РОЗВИТКУ СОЦІАЛЬНОЇ СФЕРИ УКРАЇНИ}

\author{
Уманський державний педагогічний університет імені Павла Тичини, \\ Чернігівський інститут імені Героїв Крут Приватного акиіонерного товариства «Вищий навчальний \\ заклад «Міжрегіональна Академія управління персоналом»
}

Метою статті є аналіз теоретичних положень, світового досвіду та ситуації в Україні щодо соціальної сфери, її показників, досягнень та недоліків, надання і обгрунтування пропозицій відносно шляхів розвитку, окреслення питань подальших наукових досліджень у даному спрямуванні.

Методологічною основою дослідження $є$ використання методів теоретичного узагальнення, системного підходу, аналізу, синтезу, загальнонаукових та спеціальних методів економічного 
спрямування. В результаті показано можливість вирішення протиріч між ефективністю економіки і соціальною справедливістю, використовуючи різні форми, методи та інструменти. Запропоновано інструментарій державної соціальної політики. Надано певний історичний екскурс щодо програмного вирішення соціальних проблем у країнах світу. Охарактеризовано метод планування і прогнозування організаційно-економічної форми регулювання, наведено приклади програм соціального розвитку, включаючи стратегії, довгострокові програми, а також документи регіонального характеру. Проаналізовано надання населенню субсидій за регіонами у 2019 році, де враховуються пріоритети діяльності, територіальне розташування, зусиль владних верхівок територій. Підкреслено важливість інноваційного інструментарію соціальної політики держави в умовах бюджетного дефіциту і водночас високого рівня бідності населення. Виділено такі складові соціального захисту як соціальна допомога, соціальні послуги, соціальне страхування та соціальне забезпечення. Наголошено на особливій важливості соціальної допомоги, під якою розуміється системи заходів, спрямованих на поліпшення матеріального стану певних груп населення через програми та діяльність соціальних закладів. Доведено, що необхідно впроваджувати принципи стандартизації суспільного життя, основою яких є мотивація людей до підвищення ефективності діяльності. Вказується на основні проблеми фінансування соціальної сфери та способи їх вирішення. З'ясовано взаємодію фіскальної та соціальної політики, коли фіскальна політика має стимулювати ділову активність, а ії використання тільки на збільшення надходжень до бюджету призводить до напруження у суспільстві. Підкреслюється, що головними напрямками соціального страхування $є$ захист фізичних осіб під час втрати роботи, здоров'я, засобів існування, працездатності та інше. Зазначається важливість вдосконалення роботи державної служби зайнятості для посилення ефекту від iї діяльності, а саме професійної орієнтації пошукачів роботи, забезпечення доступності соціальних послуг, набуття працюючими індивідами додаткової кваліфікації для кар'єрного зростання. Наведені та достатньо аргументовані пропозиції щодо перспектив розробки інноваційного інструментарію соціальної політики нашої держави в умовах бюджетного дефіциту і водночас бідності основної частки населення для максимального забезпечення його захисту, підвищення темпів економічного зростання, коли отримаємо дотримання високих соціальних стандартів, а також інноваційних змін революційного характеру при розробленні соціальних програм, які можуть бути використані в управлінських структурах на всіх рівнях, на підприємствах і в установах соціальної сфери.

Гострота проблеми соціального забезпечення всіх жителів країни, підсилена економічною i політичною нестабільністю протягом багатьох років і пандемією Covid 19 на даному етапі, а також недостатнє наукове і методологічне опрацювання даної проблеми провокують до послідовного вивчення, розробки та застосування у практичних діях зазначеної складової розвитку країни, особливо в частині комплексності, послідовності, реалізації кращих складових світового і багато в чому повчального вітчизняного досвіду.

Ключові слова: сочіальна політика, державне сприяння, інновації, світовий досвід, програмне забезпечення, економічне зростання, бюджетні витрати, фінансування, державно-приватне партнерство.

\title{
INNOVATIVE APPROACHES TO THE DEVELOPMENT OF THE SOCIAL SPHERE OF UKRAINE
}

\author{
PavloTychynaUman State Pedagogical University \\ Chernihiv Institute named after Heroes of Kruty PJSC Private Joint-Stock Company «Higher education \\ institution «Interregional Academy of Personnel Management»
}

The aim of the article is to analyze the theoretical provisions, world experience and the situation in Ukraine regarding the social sphere, its indicators, achievements and shortcomings, providing and justifying proposals for ways of development, outlining issues of further research in this area.

The methodological basis of the study is the use of methods of theoretical generalization, systematic approach, analysis, synthesis, general and special methods of economic orientation. As a result, the possibility of resolving the contradictions between economic efficiency and social justice is shown, using various forms, methods and tools. The tools of the state social policy are offered. A historical excursion on the program solution of social problems in the countries of the world is given. The method of cloning and forecasting of organizational and economic form of regulation is characterized, examples of social development programs are given, including strategies, long-term programs, and also documents of regional character. The provision of subsidies to the population by regions in 2019 is analyzed, which takes into account the priorities of activity, territorial location, efforts of the authorities of the territories. The importance of innovative tools of social policy of the state in the conditions of budget deficit and at the same time high level of poverty of the population is emphasized. Components of social protection such as social assistance, social services, social insurance and social security are highlighted. The special importance of social assistance is emphasized, which means a system of measures aimed at improving the material condition of certain groups of the population through programs and activities of social institutions. It is proved that it is necessary to implement the principles of standardization of public life, the basis of which is the motivation of people to increase efficiency. The main problems of financing 
the social sphere and ways to solve them are indicated. The interaction of fiscal and social policy is clarified, when fiscal policy should stimulate business activity, and its use only to increase budget revenues leads to tension in society. It is emphasized that the main areas of social insurance are the protection of individuals in the event of loss of job, health, livelihood, ability to work and more. Much attention is given tothe importance of improving the work of the state employment service to enhance the effect of its activities, namely the professional orientation of job seekers, ensuring the availability of social services, the acquisition of additional qualifications for career growth by working individuals. There are substantiated proposals on the prospects of developing innovative tools of social policy of our state in a budget deficit and at the same time poverty of the main part of the population to ensure its protection, increase economic growth, when we get high social standards, and innovative changes in developing social programs which can be used in management structures at all levels, in enterprises and institutions of the social sphere.

The severity of the problem of social security of all inhabitants of the country, exacerbated by economic and political instability for many years and the Covid 19 pandemic at this stage, as well as insufficient scientific and methodological study of this problem necessitate consistent study, development and application of this component of development in terms of complexity, consistency, implementation of the best components of world and domestic experience.

Key words: social policy, state assistance, innovations, world experience, software, economic growth, budget expenditures, financing, public-private partnership.

Постановка проблеми у загальному вигляді i їі зв'язок з важливими науковими та практичними завданнями. Ринкова економіка, яку ми переважно у первісному «дикому» вигляді досить непослідовно намагаємося впровадити вже кілька десятиріч, разом з позитивними рисами має чимало недоліків і суперечностей. Її головний стрижень (конкуренція) та ціль (прибуток) не завжди однаково сприятливі для всіх верств населення. Зменшити потенційну напругу, по можливості задовольнити запити найбільш вразливих членів суспільства має держава через форми, методи та інструменти соціальної політики, яка в ряді випадків вступає в конфлікт 3 економічними спрямуваннями, а з іншого боку, періодично викликає досить серйозні прояви невдоволення населення. В таких нелегких умовах органи державної влади мають законодавчо та нормативно забезпечити і у практичній діяльності проводити політику стабільності та узгодженості, спрямовану на гідне життя людей, одночасно партнерство з бізнесом, бачення і поетапне досягнення намічених перспектив.

Аналіз останніх досліджень, у яких започатковано вирішення проблеми. Значна кількість науковців у своїх працях вивчали теоретичні і практичні сторони діяльності держави на ринку соціальних послуг, серед них зарубіжні автори: Дж.-П. Дюмон, С. Кузнець, П. Кругман, Х. Ламперт, Т. Пікетті, Р. Стоун, а також вітчизняні вчені А. Колот, М. Корецький, І. Кравченко, Е. Лібанова, О. Макарова, В. Новіков, І. Петрова. Аналіз їх доробку показує, що інноваційний шлях розвитку єдино ефективний якщо розумно підійти до соціальної політики. В цьому напрямку і потрібно проводити подальші дослідження.

Цілі статті. Автори основними завданнями, реалізованими в ході підготовки публікації, визначили обгрунтування можливості вирішення протиріч між ефективністю економіки та соціальною справедливістю, створення інструментарію державної соціальної політики, аналіз проблем у соціальному розвитку провідних країн світу та України, з'ясування взаємодії фіскальної та соціальної політик, переваг та недоліків соціального страхування, надання пропозицій щодо інноваційного розвитку соціальної сфери та подальших досліджень у цьому спрямуванні.

Виклад основного матеріалу дослідження 3 повним обгрунтуванням отриманих наукових результатів. В усіх країнах держава у певній мірі вирішує протиріччя між ефективністю іï економіки і соціальною справедливістю, при цьому використовуючи різні форми, методи та інструментарій. Первинними $є$ форми (організаційно-економічна, інституціональна та фінансова),похідними від них методи, які, у свою чергу, включають інструменти державного впливу (рисунок 1). 


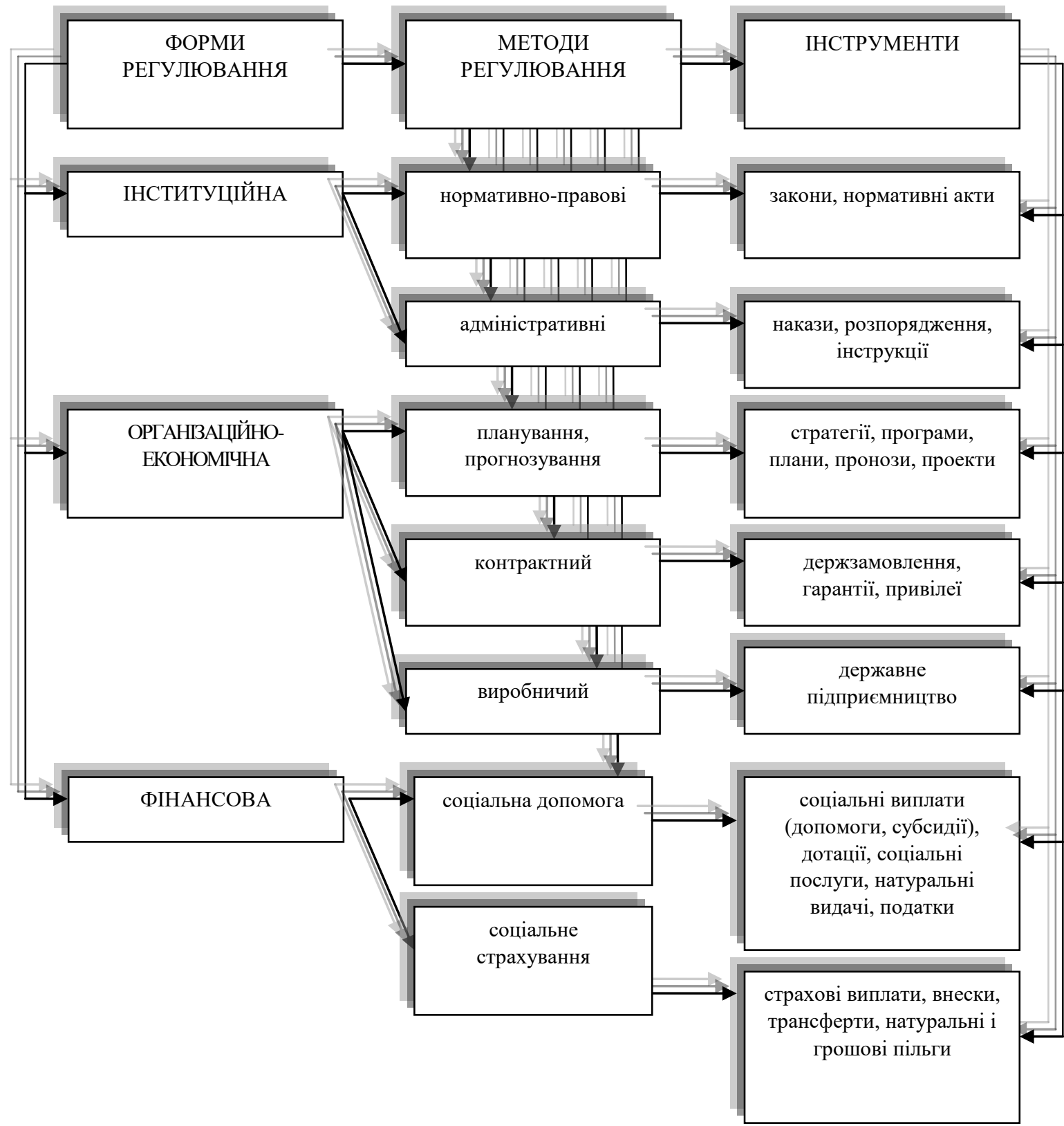

Рис. 1. Інструментарій державної соціальної політики Джерело: [1 с. 94], доопрацьоване авторами

Світовий досвід засвідчує, що зазначені складові $є$ невід‘ємними частинами профінансованих державою програм. Першими такими затвердженими на загальнонаціональному рівні документами були Програма медичного страхування i надання безкоштовної медичної допомоги у Німеччині (1880р.), Програма страхування від нещасних випадків на виробництві в Італії (1889 р.), Програма пенсійного забезпечення у Великобританії (1908 р.) та інші [2, с.89].

Розглянемо основні характеристики інструментарію. Організаційно-економічна форма використовується для організації роботи щодо виконання цілей і завдань у соціальній сфері за допомогою виробничого та контрактного методів [3]. Інституційна форма встановлює правила і норми, спрямовані на забезпечення ефективної роботи ринкової економіки в сучасних умовах, при цьому отримуючи соціальні ефекти для всіх членів суспільства через бюджетний перерозподіл прибутку та інші преференції згідно фінансової форми допомоги.

В рамках методу планування і прогнозування організаційно-економічної форми 
регулювання, на якій ми вважаємо за доцільне дещо зупинитися, є стратегії, соціальні програми, плани і прогнози. В них характеризується місце країни у світовому розвитку на початку і в кінці планового періоду, а також основні шляхи досягнення поставлених цілей. Конкретні дії по виконанню програми визначаються у концепції.

Може бути також використаний такий інструмент як регіональні програми, спрямовані на вирішення соціальних проблем окремих територій [4, с. 93-95].

У випадку, коли такі території потребують допомоги, їм надаються субсидії (таблиця 1).

Таблиця 1

Надання населенню субсидій за регіонами у 2019 році

\begin{tabular}{|c|c|c|c|c|}
\hline \multirow[t]{2}{*}{ Регіони } & \multicolumn{2}{|c|}{$\begin{array}{l}\text { Субсидії для відшкодування витрат на } \\
\text { оплату житлово-комунальних послуг }\end{array}$} & \multicolumn{2}{|c|}{$\begin{array}{c}\text { Субсидії готівкою на придбання } \\
\text { скрапленого газу, твердого та рідкого } \\
\text { пічного побутового палива } \\
\end{array}$} \\
\hline & $\begin{array}{c}\text { кількість } \\
\text { домогосподарств, } \\
\text { яким призначено } \\
\text { субсидії, тис. }\end{array}$ & $\begin{array}{c}\text { загальна сума } \\
\text { призначених } \\
\text { субсидій, тис. грн. }\end{array}$ & $\begin{array}{c}\text { кількість } \\
\text { домогосподарств, } \\
\text { яким призначено } \\
\text { субсидії, тис. }\end{array}$ & $\begin{array}{c}\text { загальна сума } \\
\text { призначених } \\
\text { субсидій, тис. } \\
\text { грн. }\end{array}$ \\
\hline 1 & 2 & 3 & 4 & 5 \\
\hline Україна & 5487,9 & 2114660,8 & 439,2 & 1366036,8 \\
\hline $\begin{array}{l}\text { Автономна Республіка } \\
\text { Крим }\end{array}$ & - & - & - & - \\
\hline $\begin{array}{l}\text { області } \\
\text { Вінницька }\end{array}$ & 303,0 & 116218,7 & 46,8 & 137548,4 \\
\hline Волинська & 176,6 & 79811,5 & 18,6 & 61310,7 \\
\hline Дніпропетровська & 252,5 & 86571,2 & 7,8 & 24108,0 \\
\hline Донецька & 415,6 & 151534,4 & 17,2 & 51774,5 \\
\hline Житомирська & 156,8 & 52287,1 & 36,6 & 109318,6 \\
\hline Закарпатська & 72,9 & 24832,1 & 15,5 & 51465,5 \\
\hline Запорізька & 320,8 & 117098,0 & 17,0 & 52486,2 \\
\hline Івано-Франківська & 180,7 & 84422,0 & 13,6 & 44504,8 \\
\hline Київська & 140,3 & 53454,0 & 6,7 & 21368,4 \\
\hline Кіровоградська & 209,1 & 70233,4 & 28,9 & 90641,1 \\
\hline Луганська & 170,6 & 59351,7 & 3,9 & 11943,0 \\
\hline Львівська & 141,9 & 83136,1 & 10,9 & 38290,6 \\
\hline Миколаївська & 111,0 & 36214,8 & 15,3 & 48749,2 \\
\hline Одеська & 208,9 & 57837,9 & 32,2 & 101331,7 \\
\hline Полтавська & 403,5 & 128617,4 & 6,2 & 18456,3 \\
\hline Рівненська & 138,3 & 75142,0 & 20,8 & 69245,7 \\
\hline Сумська & 207,1 & 52143,1 & 16,2 & 47282,0 \\
\hline Тернопільська & 115,1 & 82450,5 & 8,7 & 28432,7 \\
\hline Харківська & 464,7 & 221118,1 & 11,6 & 33814,3 \\
\hline Херсонська & 146,9 & 42007,6 & 24,5 & 81623,6 \\
\hline Хмельницька & 215,5 & 88108,0 & 18,1 & 50931,3 \\
\hline Черкаська & 251,3 & 74880,2 & 21,1 & 61323,8 \\
\hline Чернівецька & 110,9 & 34972,9 & 14,7 & 51098,1 \\
\hline Чернігівська & 305,5 & 111143,0 & 26,3 & 78874,6 \\
\hline $\begin{array}{l}\text { міста } \\
\text { Київ }\end{array}$ & 268,4 & 131075,1 & 0,0 & 113,7 \\
\hline Севастополь & - & - & - & - \\
\hline
\end{tabular}

Джерело: [5, с. 148]

3 даних таблиці проглядається нерівномірність отримання субсидій населенням залежно від пріоритетів діяльності (сільські чи міські поселення), територіального розташування, зусиль владної верхівки регіону у цьому спрямуванні та інше.

Розробка інноваційного інструментарію соціальної політики держави є дуже важливою її складовою, оскільки в умовах бюджетного дефіциту і водночас високого 
рівня бідності населення вона повинна зуміти максимально забезпечити його соціальний захист. При цьому необхідні оптимізація управління інноваційними процесами, створення умов для самореалізації різних груп населення, захисту прав i законних інтересів, узгодження державних пріоритетів із суспільними.

Складові соціального захисту: соціальна допомога; соціальні послуги; соціальне страхування; соціальне забезпечення. Вважаємо за доцільне зупинитися на соціальній допомозі, під якою розуміється система заходів, спрямованих на поліпшення матеріального стану певних груп населення через виконання соціальних програм та діяльність соціальних закладів.

Основними принципами соціальної допомоги є її адресність та першочерговість для пенсіонерів, сімей із дітьми, інвалідів. Впровадження інноваційного підходу в даному спрямуванні дозволить підвищити результативність адресності виділених коштів. При цьому необхідне виконання таких функцій: створення загальнодержавного реєстру отримувачів допомоги; розробка окремих програм соціального розвитку; встановлення критеріїв права на допомогу; виплата допомоги через банківську систему; правове забезпечення допомоги; гарантування державою рівня життя; створення і супровід єдиної бази даних; категорійний розподіл громадян - отримувачів допомоги [6, с. 85-88].

Основне завдання будь-якої країни - щорічно підвищувати темпи економічного зростання. При цьому мається на увазі, що одночасно з потужністю, місцем у світових рейтингах та інше ми у коротко- чи довгостроковій перспективі будемо мати i дотримання високих соціальних стандартів щодо рівня життя населення. Приклади подібної діяльності загальновідомі: США, Канада, Японія, країни Європейського Союзу, Китай та інші. Звичайно, і у них бувають спади, кризи, стагнації, вчені розробляють теорії невідповідності рівнів зростання економіки та показників благополуччя населення, але, на думку авторів, це шлях стабільного розвитку країн і задоволення потреб їх мешканців. Таким шляхом повинна просуватися і Україна.

При цьому необхідно впроваджувати принципи стандартизації суспільного життя, основою яких є мотивація людей до підвищення ефективності діяльності, що забезпечує економічне зростання, а в перспективі веде до посилення соціальних витрат і вимог відповідних стандартів.

Для України це повинні бути інноваційні зміни революційного характеру, оскільки з радянських часів і до наших днів довгострокові плани розвитку, незважаючи на їх назву (план соціально-економічного розвитку), в першу чергу стосувалися економічних питань, а соціальні складові переважно були другорядними i короткостроковими [7, с. 26-31].

Гострою проблемою соціальної сфери в Україні є дефіцит фінансування.

В державі розроблено багато цільових соціальних програм, але вони виконують в основному тільки обов'язкову забезпечувальну функцію (витрати на житловокомунальне господарство, заробітну плату працівників тощо). Разом 3 тим відбір об'єктів здійснюється суб'єктивно, через корупційні схеми.

Рівень задекларованих заробітних плат дуже низький, в результаті чого маємо недостатні надходження до місцевих бюджетів та фондів соціального страхування. Недосконала система підтримки підприємств, які надають послуги.

Проблеми фінансування соціальної сфери і шляхи їх подолання наведені на рисунку 2. 


\section{Основні проблеми фінансової політики соціальної сфери}

формалізоване ставлення до соціальних цільових програм;

низький рівень задекларованих заробітних плат;

неконтрольоване надання субсидій;

обмеженість ринку соціальних послуг та самого поняття «соціальні послуги»;

орієнтування системи соціального страхування на забезпечення процесу, а не на результат.

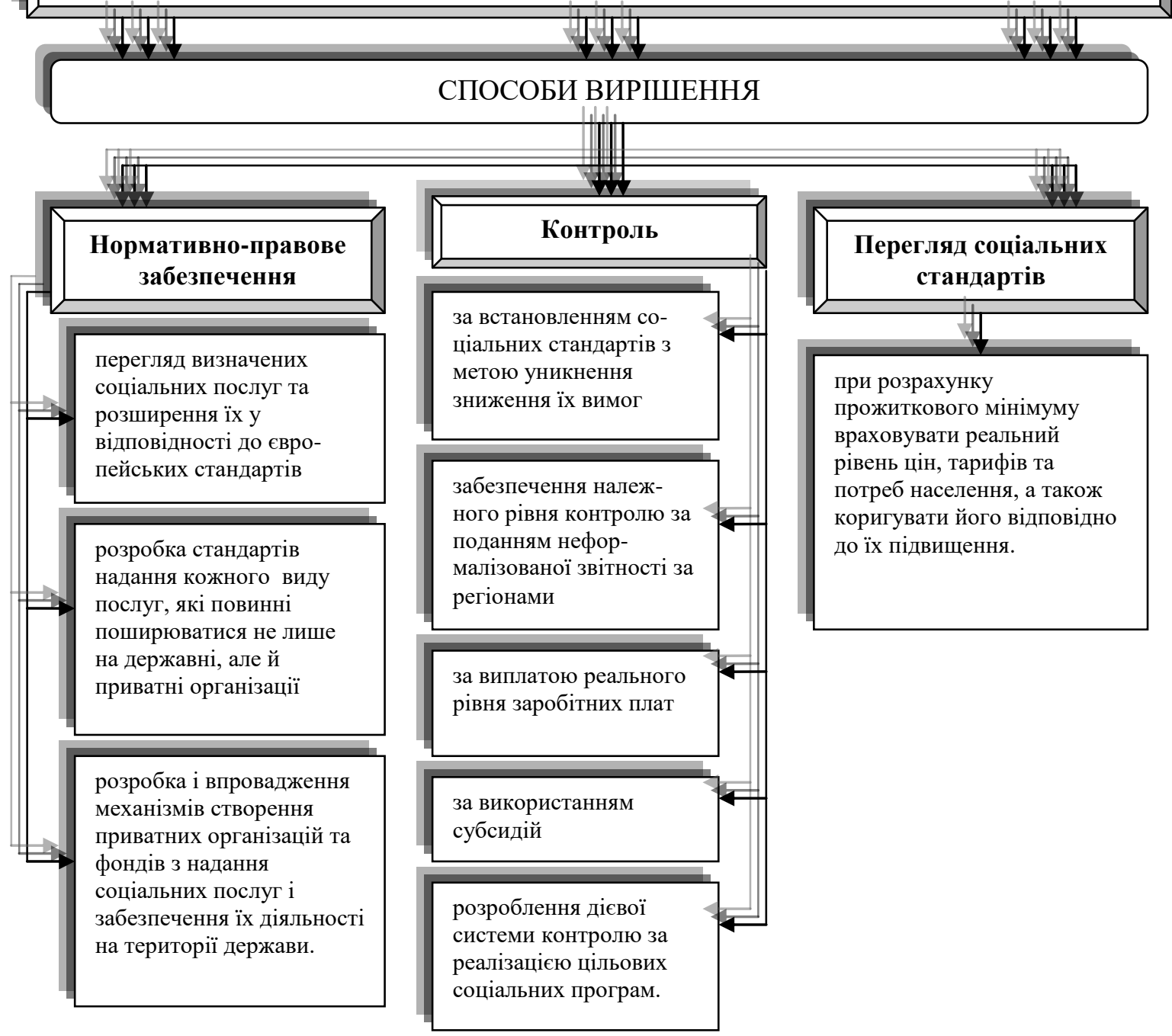

Рис. 2. Основні проблеми фінансової політики соціальної сфери в Україні та способи їх вирішення

\section{Джерело: [8, с. 5], доопращьовано авторами}

Узагальнюючи інформацію, наведену на рисунку, зазначимо, що необхідно: переглянути визначення соціальних послуг та розширити їх у відповідності із аналогічними документами $\mathrm{EC}$; впровадити механізми створення приватних організацій 3 надання послуг як альтернативи відповідним державним структурам; змінити соціальні стандарти, що суперечать потребам населення. Зміни потрібно впроваджувати комплексно, оскільки показники залежні один від одного і тільки при часткових нововведеннях ми не отримаємо бажаного ефекту. [8, с. 4-7].

В Україні треба вивчати європейські підходи до соціальної політики, щоб досягти цілей, визначених Угодою про асоціацію з Європейським Союзом, отримати рівні можливості у співпраці. При цьому ми повинні розуміти, що в Свропі чимало 
своїх невирішених питань: велика питома вага молоді без освіти, професійної підготовки і роботи; ризик бідності для значної частки населення; зростаюче соціальне розшарування суспільства.

Погіршення соціальної ситуації в Євросоюзі є наслідком скорочення соціальних витрат, зниження економічних показників, деформації соціальної моделі, загострення проблем міграції, а останнім часом і пандемії коронавірусу (Covid-19). Зросли суспільне невдоволення та його прояви на вулицях міст.

Нам важливо не породити у себе чи не посилити названі проблеми, водночас розуміючи, що їх рівень та життєвий рівень громадян значно різняться від вітчизняних. Крім того, там бачать зазначені деформації i використовують заходи для їх пом'якшення чи взагалі усунення. Для прикладу, у 2016 році було висунуто для обговорення проект «Європейська опора соціальних прав» («European Pillar of Social Rights»), де запропоновано консолідовані принципи у сфері ефективно функціонуючих ринків праці і систем соціального забезпечення в країнах $\mathrm{С} 3$ такими складовими: гідні умови праці; однакові можливості щодо працевлаштування; доступ до соціальних послуг високої якості; стабільний соціальний захист.

При цьому задекларовано, що на всій території країн Свропейського Союзу така політика соціальної справедливості повинна: опиратися на модель економічного зростання; мати комплексний характер; охоплювати зайнятість та соціальні інвестиції; своєчасно нейтралізувати негативний вплив ризиків у розвитку [9, с. 51-63].

Впровадження фіскальної політики на всіх рівнях повинно бути тісно пов'язане із соціальною політикою країни, сприяти соціальному захисту населення, стимулювати інновації та розвиток виробництва, а також інвестиційну привабливість.

Важливо не допустити збільшення безробіття, посилення «тінізації» економічних процесів, а в результаті - зменшення надходжень до бюджетів всіх рівнів та зростання соціальної допомоги по безробіттю. Інакше уряд буде змушений нарощувати субсидії непрацюючим поки вони не знайдуть роботу, що вкрай важко при подібній ситуації.

Збільшення прожиткового мінімуму і мінімальної заробітної плати останніми роками (відповідні постанови уряду) без зростання виробництва провокують вивільнення персоналу чи його переведення на неповний робочий день. Фактично маємо протилежну спрямованість нововведень у фіскальній та соціальній політиці.

Інструменти фіскальної політики мають стимулювати ділову активність. Використання їх тільки для збільшення надходжень до бюджету призводить до напруження у соціальній сфері, посилює еміграцію працездатного населення, нарощує навантаження на бюджет в частині надання компенсаційних виплат різного типу [10, с. 63-65].

Головні напрямки соціального страхування - захист фізичних осіб під час втрати роботи, здоров'я, засобів існування, працездатності та інше. Економічний спад в результаті невдалого реформування, а також тимчасової втрати територій Криму i частини Донбасу, військових дії на Сході країни зумовили появу нових видів економічних та соціальних ризиків, що вимагає впровадження механізмів захисту населення від їх впливу. Одним 3 таких механізмів є якраз соціальне страхування, завдяки якому вирішуються такі завдання: скорочується розрив у матеріальному забезпеченні працюючих та безробітних; формуються грошові фонди.

В Україні працюють три позабюджетні цільові фонди: Пенсійний фонд, Фонд соціального страхування і Фонд загальнообов'язкового державного страхування на випадок безробіття.

Втрата працездатності, обумовлена досягненням пенсійного віку, катастрофічно зменшує доходи населення. Необхідно також враховувати, що ціни на першочергово необхідні вироби та послуги швидко зростають. Для прикладу, у 2017 році до попереднього періоду вони підвищилися на: продукти харчування в середньому $113,4 \%$; м'ясо та м'ясопродукти - 120,9\%; молоко, сир та яйця $-120,8 \%$; фрукти - 
115,2\%; житло, воду, електроенергію, газ та інші види палива - 126,7\%; транспорт $114,2 \%$; освіту - 111,9\%; охорону здоров'я - 106,2\% [11, с. 234]. Подібні тенденції збереглися і навіть посилилися в подальшому.

Розвиток соціального страхування, як невід‘ємної складової соціальної політики передбачає: посилення прозорості роботи фондів соціального страхування; інформування суспільства щодо діяльності фондів; введення обов'язкового медичного страхування; задіяння корпоративних схем для пенсійного забезпечення професій, пов'язаних з ризиком для життя; запровадження накопичувальної системи пенсійного страхування, що можливе тільки при економічній стабільності, поверненні довіри населення до банківської системи, інвестиційному зростанні накопичень, інноваційних підходах щодо діяльності [12, с. 70-75].

Більш детально розглянемо ситуацію 3 безробіттям як одним 3 головних чинників кризового стану фінансового забезпечення жителів. Близько половини безробітних - люди 3 вищою освітою, а серед них - працівники сфери державного управління (кожен п'ятий серед зареєстрованих безробітних). Зростає питома вага учасників АТО - 7\%, а в окремих регіонах до $12 \%$.

Ситуація на Сході України потребує створення додаткових робочих місць на підприємствах військово-промислового комплексу, а також працевлаштування внутрішньо переміщених осіб, демобілізованих учасників антитерористичної операції. Зазначене вимагає модернізації державної служби зайнятості для посилення ефекту від iii діяльності, а саме: професійної орієнтації пошукачів роботи; забезпечення доступності соціальних послуг для всіх верств населення, в тому числі через соціальне партнерство; набуття працюючими додаткової кваліфікації для кар'єрного зростання.

Потребують подальшого вдосконалення центри професійно-технічної освіти. Професійно-технічні заклади мали потужну матеріальну базу, яка в основному збереглася. Ї̈і необхідно використати для надання платних послуг. Перелік професій на сьогодні налічує 77 одиниць і навчання повинно відповідати потребам конкретних регіонів та їх підприємств.

Враховуючи нестабільну економічну і фінансову ситуацію в країні, інноваційні підходи вимагають реалізації головного завдання - першочергового працевлаштування тих, хто втратив роботу або активно шукає потрібний йому вид діяльності. Це забезпечить повернення до зайнятості та, відповідно, зменшення видатків на виплату соціальної допомоги.

Розуміючи ситуацію економічної нестабільності, поглиблену коронавірусом, потрібні: всебічна організація дистанційного навчання, розширення переліку професій, в тому числі найбільш сучасних, інформування населення і суб'єктів господарювання, врахування потреби в робочій силі для нових інфраструктурних проектів, співпраця 3 територіальними громадами, результатом чого може стати збільшення тимчасової зайнятості через залучення безробітних до громадських робіт, які оплачуються 3 місцевих бюджетів [13, с. 3-6].

В даному дослідженні, через його обсяги, ми не змогли, та і не ставили перед собою за мету, охопити такі надзвичайно важливі питання соціальної політики як освіта та охорона здоров'я. Це тема окремих напрацювань авторів, які включають дані проблеми у сферу своїх наукових інтересів.

Висновки. Розробка інноваційного інструментарію соціальної політики нашої держави є дуже важливою іiі проблемою, оскільки в умовах бюджетного дефіциту i водночас бідності основної частини населення вона повинна зуміти максимально забезпечити його соціальний захист.

Основне завдання будь-якої країни - щорічно підвищувати темпи економічного зростання, коли одночасно з потужністю, місцем у світових рейтингах та інше ми у коротко-, а особливо у довгостроковій перспективі будемо мати дотримання високих соціальних стандартів щодо рівня життя населення. На думку авторів, це шлях стабільного розвитку країни і задоволення потреб ії мешканців. Таким шляхом має 
просуватися і Україна.

Для нашої держави зазначене повинно здійснюватися як інноваційні зміни революційного характеру, оскільки з радянських часів і до наших днів довгострокові програми розвитку в першу чергу стосувалися економічних питань, а соціальні складові переважно були короткостроковими і другорядними.

В подальших наукових розвідках цього спрямування вважаємо за доцільне поглиблене вивчення зазначених питань, досягнення взаємопов'язаності окремих складових, розробку чітко окресленої стратегії інноваційного розвитку соціальної сфери та концепції іiі програмного забезпечення на засадах державно-приватного партнерства.

\section{Список бібліографічного опису}

1. Waddock S.A. Understanding Social Partnerships: An Evolutionary Model of Partnerships Organizations / S.A. Waddock // Administration \& Society. 1989. Vol. 21, No. 1. P. 78-100.

2. Dumon J -P. Les systems de protection sociale en Europe / J -P. Dumon. Paris: Economica, 1998. P.126

3. Григорьева Н. С. Социальные потребности и социальная политика в достижении благосостояния: роль международных организаций в реформе социальной сферы стран переходной экономики / Н.С. Григорьева / Государственное управление. Электронный вестник // Вып. № 6. 10 августа. 2011 г. (Электронный ресурс). Режим доступу: http://e-journal/spa.-msu.ru/images/File/grigorjeva.pdf

4. Бандура І. С. Соціальна держава як результат ефективної соціальної політики / I. С. Бандура // Інвестиції: практика та досвід. 2016. № 12. С. 93-95.

5. Статистичний щорічник України 2019 // Державна служба статистики України. - за редакцією I.С. Вернара. К. 2020. $464 \mathrm{c}$.

6. Кайда О. П. Інноваційні підходи до формування інструментарію реалізації соціальної політики держави / О.П. Кайда // Інвестиції: практика та досвід. 2016. №23. С. 85-88.

7. Багратян Г. А. Соціальна політика та ефективність економіки / Г. А. Багратян, I. А. Кліпа // Ринок праці та зайнятість населення. 2018. № 1. С. 26-31.

8. Гордієнко Л. А. Проблеми та напрями удосконалення фінансової політики соціальної сфери України / Л. А. Гордієнко // Економіка. Фінанси. Право. 2016. № 7. С. 4-7.

9. Бурлай Т. Сучасна політика Євросоюзу в контексті соціальної справедливості / Т. Бурлай // Економічна теорія. 2016. № 4. C. 51-64.

10. Морщ Я. І. Реалізація фіскальної та соціальної політики України: точки дотику з реальністю / Я. І. Морщ // Держава та регіони. Серія Економіка та підприємництво . 2017. № 2. С. 62-66.

11. Статистичний щоденник України за 2017 рік / Державна служба статистики України. - за редакцією I. Є. Вернара. 2018. $542 \mathrm{c}$.

12. Козоріз Г. Г. Соціальне страхування як елемент державної соціальної політики / Г. Г. Козоріз // Регіональна економіка. 2016. № 1. С. 70-77.

13. Ярошенко В. С. Модернізація державної служби зайнятості як складник сучасної соціальної політики України / В. С. Ярошенко // Ринок праці та зайнятість населення. 2016. № 4. С. 3-6.

\section{References}

1. Waddock, S.A. Understanding Social Partnerships: An Evolutionary Model of Partnerships Organizations (1989).Administration \& Society, 21(1), 78-100.

2. Dumon, J.-P. (1998). Les systems de protection sociale en Europe. Paris: Economica, p.126.

3. Grigorieva, N.S.(2011). Social needs and social policy in achieving welfare: the role of international organizations in the reform of the social sphere of countries with transition economies. Public administration. Electronic Bulletin, 6. Retrieved from:http://e-journal/spa.-msu.ru/images/File/grigorjeva.pdf[in Ukrainian].

4. Bandura, I.S. (2016). The social state as a result of effective social policy.Investments: practice and experience, 12, $93-$ 95 [in Ukrainian].

5. Statistical Yearbook of Ukraine. 2019.(2020).I. Ye. Werner (Ed.). Kyiv: State Statistics Service of Ukraine[in Ukrainian].

6. Kaida, O.P.(2016). Innovative approaches to the formation of tools for the implementation of social policy of the state. Investments: practice and experience, $23,85-88$ [in Ukrainian].

7. Bagratyan, G.A.\&Klipa, I.A. (2018).Social policy and efficiency of economy.Labor market and employment,1, 26-31[in Ukrainian].

8. Gordienko, L.A.(2016). Problems and directions of improving the financial policy of the social sphere of Ukraine.Economy. Finances. Right, 7, 4-7[in Ukrainian].

9. Burlay, T. (2016). Contemporary policy of the European Union in the context of social justice.Economic theory, 4, 51$64[$ in Ukrainian].

10. Morshch, J.I.(2017).Realization of fiscal and social policy of Ukraine: points of contact with reality. State and Regions. Series Economics and Entrepreneurship, 2, 62-66[in Ukrainian].

11. Statistical Yearbook of Ukraine. 2017.(2018).I. Ye. Werner (Ed.). Kyiv: State Statistics Service of Ukraine[in Ukrainian].

12. Kozoriz, G.G.(2016). Social insurance as an element of state social policy. Regional economy, 1, 70-77[in Ukrainian].

13. Yaroshenko, V.S.(2016).Modernization of the state employment service as a component of modern social policy of Ukraine. Labor market and employment, 4, 3-6[in Ukrainian].

Дата подання публікації 3.03.2021p. 